\title{
REDUCTION IN RADIATION (FLUOROSCOPY) WHILE MAINTAINING SAFE PLACEMENT OF PEDICLE SCREWS DURING LUMBAR SPINE FUSION
}

\author{
REDUÇÃO DA RADIAÇÃO (FLUOROSCOPIA) E MANUTENÇÃO DA COLOCAÇÃO SEGURA \\ DOS PARAFUSOS PEDICULARES NA ARTRODESE LOMBAR
}

\author{
REDUCCIÓN DE LA RADIACIÓN (FLUOROSCOPÍA) MIENTRAS SE MANTIENE LA \\ COLOCACIÓN SEGURA DE TORNILLOS PEDICULADOS DURANTE \\ ARTRODESIS DE LA COLUMNA LUMBAR
}

Christopher D. Chaput ${ }^{1}$, Keri George ${ }^{2}$, Amer F. Samdani ${ }^{3}$, John I. Williams ${ }^{4}$, John Gaughan ${ }^{5}$, Randal R. Betz ${ }^{3}$

\begin{abstract}
Objective: The purpose of this study is to report the results using PediGuard (electrical conductivity device) to reduce radiation exposure while drilling the pilot hole for pedicle screw placement. Method: Eighteen patients diagnosed with a degenerative lumbar spine, that required a posterior spinal fusion. Average age of the patients were $55 \pm 12$ years. Patients received postoperative CT scans of all screws. Scans were reviewed by an independent reviewer grading 'in' $<2 \mathrm{~mm}$ of breach, or 'out' $\geq 2 \mathrm{~mm}$ of breach. In a randomized fashion, the surgeon created pilot holes with either his standard technique or by using the PediGuard. Fluoroscopy was used for each drilling as necessary. Once the pilot hole was created, the surgeon inserted titanium screws into the pedicle pilot holes. A total of 78 screws (39 standard probe and 39 PediGuard) were analyzed. Results: 78 screws (39 standard probe and 39 PediGuard were analyzed. No significant difference in breach rate $>2 \mathrm{~mm}$ by either method $(p=1.000)$, with one screw out in each group. Fluoroscopy shots averaged 5.2 (range, 0 to 15), average decrease of 2.3 (30\%) per screw in the PediGuard group vs. 7.5 (range, 2 to 17) in the standard group ( $p<.001$ ). Conclusion: This trial to assess pedicle probe location within the pedicle and vertebral body showed the number of fluoroscopy shots were reduced by $30 \%$, compared to a standard probe while maintaining a $97.5 \%$ screw placement accuracy.
\end{abstract}

Keywords: Fluoroscopy; Bone screws; Spine; Lumbar vertebrae; Radiation exposure.

\section{RESUMO}

Objetivo: Relatar os resultados do uso do dispositivo PediGuard para reduzir a exposição à radiação durante a perfuração do orifício piloto para a colocação do parafuso pedicular. Métodos: Dezoito pacientes com diagnóstico de doença degenerative da coluna lombar e submetidos à artrodese posterior (todos pelo investigador principal [CDC]) foram incluídos no estudo. A idade média dos pacientes era de $55 \pm 12$ anos. No pós-operatório foi realizada tomografia computadorizada em todos os pacientes para avaliação do posicionamento dos parafusos. Os exames foram revisados por um avaliador independente. Os parafusos foram considerados no interior do pedículo quando o rompimento da cortical era menor que $2 \mathrm{~mm}$, e localizados for a quando o rompimento era maior que $2 \mathrm{~mm}$. O orificio piloto foi re alizado foi realizado de modo randomizado por meio de sonda ou utilizando o PediGuard, tendo sido utilizada a fluoroscopia quando necessario. Parafusos pediculares de titânio foram utilizados de acordo com a técnica padrão. Foram utilizados 78 parafusos de titânio de acordo com a técnica padrão, 39 parafusos com orificio piloto realizado com sonda e 39 parafusos com orificio piloto realizado com o PediGuard. Resultados: Não houve diferença significativa na taxa de rompimento do pedículo $>2$ milímetros por qualquer um dos dois métodos $(p=1,000)$, tendo sido observado apenas 1 parafuso fora do pedículo vertebral em ambos os grupos. A media da utilização da fluoroscopia foi 5,2 disparos (variando de 0 a 15) por parafuso no grupo PediGuard vs 7,5 (variando de 2 a 17) no grupo em que a sonda foi utilizada ( $p<0,0001)$. Foi observada redução média de 2,3 disparos (30\%) por parafuso com a utilização do PediGuard. Foram realizados 202 disparos na fluoroscopia no grupo do PediGuard e 293 no grupo padrão. Conclusões: Neste estudo prospectivo e randomizado foi obsenado que a utilização do PediGuard para o prepare do orifício piloto reduz os disparos da fluoroscopia em 30\% em comparação com a utilização de sonda, mantendo a precisão da colocação do parafuso pedicular em 97,5\% das perfurações.

Descritores: Fluoroscopia; Parafusos ósseos; Coluna vertebral; Vértebras lombares; Exposição a radiação.

\section{RESUMEN}

Objetivo: La finalidad de este estudio es relatar los resultados al usar PediGuard (dispositivo de diferenciación de conductividad eléctrica) para reducir la exposición a la radiación al perforar el orificio piloto para la colocación de tornillos pediculares. Método: Dieciocho pacientes con diagnóstico de degeneración de la columna lumbar, que precisaban artrodesis espinal posterior. El promedio de edad de los pacientes fue $55 \pm 12$ años. Los pacientes fueron sometidos a TC de todos los tornillos después de la cirugía. Las TC fueron analizadas por un revisor independiente y graduadas como 'dentro' $<2 \mathrm{~mm}$ de vacío o 'fuera' $\geq 2 \mathrm{~mm}$ de vacío. De modo aleatorio, el cirujano creó orificios piloto con su técnica estándar o usando PediGuard. La fluoroscopía fue usada para cada perforación, de acuerdo a la necesidad. Una vez

1. Temple Clinic, Temple, TX, USA.

2. San Francisco, CA, USA

3. Shriners Hospitals for Children, Philadelphia, Philadelphia, PA, USA.

4. Parkview Hospital, Fort Wayne, IN, USA.

5. Temple University School of Medicine, Philadelphia, PA, USA.

Studt conducted at Scott and White Memorial Hospital, 2401, S 31st St Temple, TX, USA 76504.

Mailling Adress: 1388 Sutter Street Suite 510, San Francisco, CA 94109. E-mail: Keri.george@telus.net

Received em 16/03/2013, accepted em 17/05/2013. 
creado el orificio piloto, el cirujano insertó tornillos de titanio en los orificios pediculares pilotos. Fue analizado un total de 78 tornillos (39 con sonda estándar y 39 con PediGuard). Resultados: Fueron analizados setenta y ocho tornillos (39 con sonda estándar y 39 con PediGuard). No fue encontrada diferencia significativa en la tasa de vacíos $>2 \mathrm{~mm}$ en ninguno de los métodos $(p=1,000)$, con un tornillo fuera en cada grupo. Cada inyección de fluoroscopía fue en promedio 5,2 (franja 0 a 15), la reducción media fue 2,3 (30\%) por tornillo en el grupo PediGuard en comparación con 7,5 (franja 2 a 17) en el grupo estándar ( $p<0,001$ ). Conclusión: Este estudio evalúa la ubicación de la sonda pedicular en el interior del pedículo y el cuerpo vertebral mostró que el número de inyecciones de fluoroscopía fue reducido en $30 \%$ en comparación con la sonda estándar, al mismo tiempo en que mantuvo la precisión de 97,5\% en la colocación del tornillo.

Descriptores: Fluoroscopía, Tornillos óseos; columna vertebral; Vértebras lumbares; Exposición a la radiación.

\section{INTRODUCTION}

Pedicle screw fixation has been shown to be superior to other methods of instrumentation of the spine for spinal fusion and correction of spine deformity. ${ }^{1-7}$ In a meta-analysis of the literature by Yahiro ${ }^{8}$ of 5,756 patients reported in 101 articles, the success of fusions with pedicle screws was $94.8 \%$, attesting to the clinical usefulness of pedicle screw instrumentation. However, one of the complications of pedicle screw placement is pedicle perforation.

Perforation rates range from 2.5 to $40 \% .^{9,10-12}$ Many of the differences in the literature depend on the study methodology used to determine the perforation. Perforations can further lead to complications such as dural tear, ${ }^{12}$ nerve root injuries, ${ }^{12}$ paraplegia, ${ }^{12-15}$ or vascular injury. ${ }^{16}$ In a large series of 2,187 patients with degenerative spondylolisthesis, ${ }^{17} 5 \%$ had intraoperative adverse events associated with the technical aspects of screw insertion. Nerve root injury, spinal cord injury, and vascular injury occurred in $1 \%$ of patients. Radicular pain occurred in $1.5 \%$ of patients, and dural tears occurred in $0.5 \%$. In a meta-analysis of the literature of 5,756 patients reported in 101 articles, there were 65 dural tears $(1.1 \%)$ and 99 neural injuries $(1.7 \%){ }^{8}$

Many surgeons employ a manual technique of preparing the pedicle hole with a pedicle probe. The "Freehand Technique" is based on knowledge of spinal anatomy. This technique results in the least radiation exposure to the patient and surgeon but is less accurate in placing contained pedicle screws as compared to imaging techniques. ${ }^{18}$ A fluoroscopic technique may provide more consistent results but carries some risks associated with radiation dose, especially to young patients ${ }^{19,20}$ and to the surgeon. ${ }^{20}$

This manual PediGuard technique most closely matches the freehand manual technique. The PediGuard is a pedicle probe but provides the surgeon with additional feedback in the form of an audible tone when a breech has occurred or is about to occur. This theoretically gives the surgeon additional opportunity to prepare a contained pilot hole without additional radiation exposure.

The purpose of this prospective randomized, controlled study is to report the results of using the PediGuard device to reduce radiation exposure while drilling the pilot hole for pedicle screw placement.

\section{MATERIALS AND METHODS}

Eighteen patients with a diagnosis of lumbar degenerative spine having a posterior spinal fusion (all by the principal investigator [CDC]) were enrolled in the study. The average age of the patients was $55 \pm 12$ years. In a randomized fashion, the surgeon placed a pilot hole either with a standard technique (manual probe) or the PediGuard device and used fluoroscopy for each drilling as a guidance assist as necessary. Every pedicle screw insertion (as opposed to subject) was randomized by an alternating technique using either a standard probe or the PediGuard probe. The first pedicle was probed at either the most distal or most proximal vertebra to be instrumented. Then, the opposite pedicle at the same level was drilled using the technique not used initially. At each subsequent level, the technique used on each side was reversed. For example, if at L3 the PediGuard was used on the left and surgeon's procedure on the right, then at $L 2$ the PediGuard will be used on the right and surgeon's procedure on the left, and this process was continued until all levels were instrumented. Once the pilot hole was placed, the surgeon inserted the titanium screws in his standard fashion. EMG testing was not done by the surgeon. A total of 78 screws (39 via standard probe and 39 with PediGuard assist) were analyzed.

The PediGuard tool to be used in this study is a $510(\mathrm{k})$ approved device for pedicle screw fixation manufactured by SpineGuard, Inc. The PediGuard system consists of an awl instrument with is a perforation detecting instrument with an impedance measurement capability at the tip. The electrical impedance changes as the instrument passes through cancellous and cortical bone as well as soft tissue. ${ }^{21}$ When the electrical impedance at the tip of the PediGuard changes, the surgeon is alerted to this change via audible and visual means. The PediGuard is used in an anticipatory function during drilling of the vertebral pedicle. Due to the shape of the electromagnetic field at the tip of the device, the pitch and cadence of the sound emitted slightly changes before the nature of the bone or tissue changes. When first entering the cancellous bone, keeping firm pressure is necessary to get a sense of the rate and pitch of the sound for that particular pedicle. As one advances, if the rate and pitch slow, then one is probably near or up against cortical bone. One can then gently reangle the tip, keeping firm pressure to look for the original sound of the cancellous bone. Once the sound of the original cancellous bone is heard, then one should advance the PediGuard in that direction. It is extremely important to not decrease pressure of the tip on the bone, or blood will intervene, and then a very high pitch and rate of sound will result. In addition, if one angles the tip too far in any one direction, then blood will seep in and surround the electrode tips, and a high pitched, high cadence sound will be heard as a consequence of the tip measuring blood.

Each subject had a full neurologic exam at discharge or their first outpatient follow up visit. All patients had a CT scan of all screws placed. These scans were reviewed by an independent reviewer (AFS) Perforations $\leq 2 \mathrm{~mm}$ on CT scan are thought not to be associated with clinical sequelae, ${ }^{22}$ and other authors report perforations as large as $4 \mathrm{~mm}$ being associated with no problems. ${ }^{23}$ Gertzbein and Robbins ${ }^{24}$ reported an incidence of medial cortical penetration up to $8 \mathrm{~mm}$ with two minor neurological injuries. They hypothesize a $4 \mathrm{~mm}$ safe zone, which includes $2 \mathrm{~mm}$ of epidural space and $2 \mathrm{~mm}$ of subarachnoid space. Belmont et al. ${ }^{9}$ considered screw penetration of the medial pedicle wall less than or equal to $2 \mathrm{~mm}$ to be acceptable. We considered $2 \mathrm{~mm}$ or less of screw perforation to be acceptable in this study. Screws were considered 'in' ( $<2 \mathrm{~mm}$ of breech [considered clinically insignificant]), or 'out' ( $\geq 2 \mathrm{~mm}$ of breach [possibly clinically significant]).

\section{Data analysis}

Breach rates were compared (PediGuard versus manual) using Fisher's exact test. The number of fluoroscopy shots were analyzed using a repeated measures ANOVA on normalized ranks comparing PediGuard and manual methods of placement. All analyses were carried out using SAS V9.1.3 software (SAS Institute, Cary, NC).

\section{RESULTS}

There was no significant difference in breach rate $\geq 2 \mathrm{~mm}$ by either of the two methods $(p=1.000)$, with one screw out in each group. Both were medial breaches, one L4, one L5. (Figure 1 A, B) Fluoroscopy 
shots averaged 5.2 (range, 0 to 15) per screw in the PediGuard group vs. 7.5 (range, 2 to 17) in the standard group $(p<.001)$. This represents an average decrease of $2.3(30 \%)$ fluoro shots per screw with PediGuard. There were 202 total fluoro shots used in the PediGuard group vs. 293 in the standard group. (Table 1)

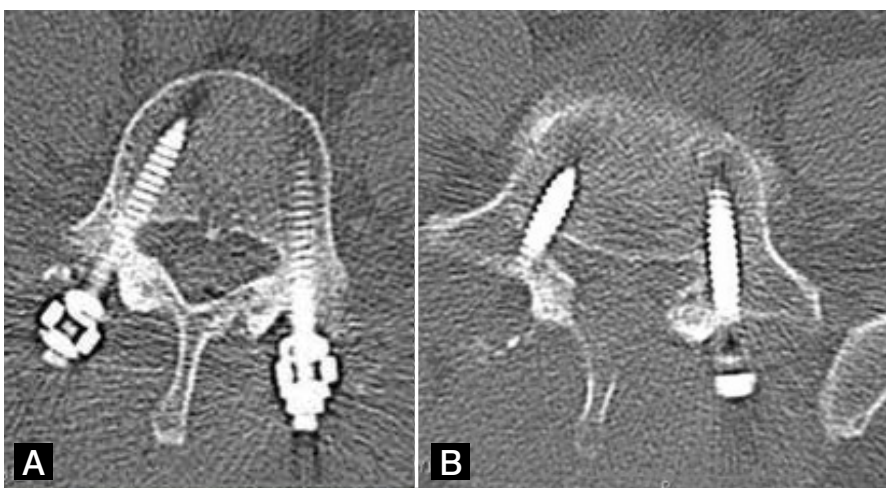

Figura 1. A) Patient 1: L5 R PediGuard. B) Patient 4: L5 R Standard.

Table 1. Results of pedicle screw placement using PediGuard or standard manual probe

\begin{tabular}{c|c|c|c|c}
\hline & & \multicolumn{2}{|c}{ \# Fluoro shots } \\
\hline & $\begin{array}{c}\text { In (or }<\mathbf{2 m m} \\
\text { breach) }\end{array}$ & $\begin{array}{c}\text { Out (or } \geq 2 \mathbf{m m} \\
\text { breach) }\end{array}$ & Mean & SD \\
\hline $\begin{array}{c}\text { Standard manual } \\
\text { technique (N=39) }\end{array}$ & $38(97.5 \%)$ & $1(2.5 \%)$ & 7.5 (range, 2-17) & 3.60 \\
\hline $\begin{array}{c}\text { PediGuard } \\
\text { technique (N=39) }\end{array}$ & $38(97.5 \%)$ & $1(2.5 \%)$ & 5.2 (range, 0-15) & 3.30 \\
\hline
\end{tabular}

\section{DISCUSSION}

The major clinical significance of this study is the opportunity to reduce radiation exposure to the surgeon while maintaining safe pedicle screw placement for the patient. No patient in either group had a new radiculopathy or new neurologic deficit. Since patients were prospectively evaluated neurologically and follow up was $100 \%$, this study provides high level evidence that the PediGuard can provide safe pedicle screw placement similar to placement with standard techniques that are more heavily dependent on fluoroscopic imaging.

One advantage of this study is that postoperative CT scans for assessment of screw breach were obtained in all cases. The use of all titanium screws improved the accuracy of the review for screw breech. Studies using a postoperative CT scan reviewed by independent or blinded reviewers show higher rates of perforation than those determined by radiograph. Laine et al. ${ }^{23}$ reviewed 30 low back operations. In this series of 152 pedicle screws, 32 screw perforations (21\%) were detected by CT scan, whereas only 3 were detected by plain radiographs. Screws perforated less than $4 \mathrm{~mm}$ caused no neurological problems. In only 10 of the 30 patients were all the screws located within the pedicle. Many surgeons rely on plain radiographs to assess screw perforation postoperatively. However, the number of malpositioned screws are underestimated. In an article by Learch et al. ${ }^{25}$ using cadaver specimens of the lumbar spine, only $63 \%$ of the screws' positions were correctly identified on radiograph as compared to $87 \%$ with CT scan.

Weinstein et al. ${ }^{26}$ wrote a classic article on the use of fluoroscopic guidance for screw placement in cadaver specimens in which any evidence of cortical perforation was considered to be a failure of screw placement. This occurred in $21 \%$ of the screws placed where direct visualization was the definite endpoint. Of the screws demonstrating perforations, 92\% were medial, potentially injuring the spinal cord or a nerve root. Additional variations exist -- for example, using anatomic placement for the anteroposterior (AP) positioning of the fluoroscopy for sagittal guidance. ${ }^{27}$ The basic concept is that fluoroscopy is used to guide each drill hole instead of just confirming screw placement. Use of fluoroscopy, however, is inefficient, especially with the time involved in switching from AP to lateral views. In addition, it is ergonomically obstructive and may expose the surgeon and patient to potentially hazardous amounts of radiation. ${ }^{28,29}$ Fluoroscopic techniques have been reported to have relatively high false-negative rates. ${ }^{30}$

A study by $\mathrm{UI}$ Haque et $\mathrm{al}^{20}$ on radiation exposure with all screw constructs in adolescent idiopathic scoliosis showed that a nonclassified radiation worker (i.e. the surgeon) inserting approximately 2,800 screws under fluoroscopic guidance is projected to receive $13.49 \mathrm{mSv}$ of whole body ionizing radiation and 4.31 $\mathrm{mSv}$ of thyroid gland irradiation annually. The National Council on Radiation Protection's current recommendations set lifetime dose equivalent limits for classified workers (radiologists) at $10 \mathrm{mSv}$ per year of life and at $3 \mathrm{mSv}$ for nonclassified workers (spine surgeons). At the levels estimated, a surgeon beginning his/her career at age 30 years would exceed the lifetime limit for nonclassified workers in less than 10 years.

A study by Rampersaud et al. ${ }^{28}$ reported that surgeons may be exposed to 10-12 times greater radiograph radiation dose rates during fluoroscopically assisted pedicle screw insertion than during other nonspinal musculoskeletal procedures. This is primarily due to the increased energy required to fluoroscopically image the lumbar spine and the proximity of the surgeon's hands to the primary and backscatter sources of radiation that occur during this imaging. Currently, established guidelines recommend monitoring for personnel who are exposed to greater than $10 \%$ of the maximum permissible annual whole-body dose. ${ }^{21,28,29}$ Given a permissible whole-body dose of 5000 mrem per year, the levels of radiation exposure documented in this study would place many spine surgeons above this $10 \%$ limit.

Three-dimensional image-guidance systems allow the surgeon to visualize patient-specific imaging along surgically relevant planes both pre-and intraoperatively. Image-guided surgery utilizing preoperative CT scans or intraoperative fluoroscopy have been promoted to give better accuracy of pedicle screw placement. Laine et al. ${ }^{18}$ showed in a randomized study a reduction in the perforation rate from $13.4 \%$ in a conventional group to $4.6 \%$ in a computer assisted image guided group. However, this technique has not become popular because of the initial cost $(\$ 200,000)$, the added surgical time, and the need to reregister the system for each vertebral level being instrumented. ${ }^{29}$ This technique requires less radiation exposure than fluoroscopy. ${ }^{29}$ Since 3-D image guidance is not in widespread use, we did not compare it to the PediGuard.

This is not a screw insertion technique per se; it is another method similar to radiograph to confirm safe position of the pilot probe (stimulation of the probe) or the screw (stimulation of the screw). Stimulus thresholds are listed in Table 1. Clements et al report thresholds above $10 \mathrm{mAmps}$ as being associated with no postoperative nerve root radiculopathies. ${ }^{31}$

Some surgeons like to use EMG stimulation of the probe for muscle contraction to assist in determining pedicle wall breaches before inserting the pedicle screw. The PediGuard may be used in conjunction with any standard EMG monitoring system to detect contraction of muscles. An EMG monitor is not provided with the PediGuard system. As is standard in the use of an EMG monitor, leads should be strategically placed on the patient's legs and attached to the monitor so that the monitor will register muscle contraction in the leg should the PediGuard stimulate a corresponding nerve in the spine.

Previous studies with the PediGuard. Bolger et al. ${ }^{32}$ reported 147 manual pedicle drillings performed in 11 hospitals during 28 spinal surgeries between September 2002 and March 2003. The purpose of the study was to determine perforations detected by: 1) the PediGuard; 2) the physician; and 3) both the PediGuard and the physician. A total of 23 vertebral cortex perforations out of the 
147 manual pedicle drillings (16\%) were confirmed, 22 of which (95.7\%) were detected by the PediGuard during the procedure. A total of 12 vertebral cortex perforations (52.2\%) were detected by the PediGuard but not by the physician, while only one vertebral cortex perforation (4.3\%) was detected by the physician but not by the PediGuard.

Each investigator used the instrument(s) available at their facility to check for perforations during surgery to confirm whether a breach occurred. The surgical instruments used to check for perforations during surgery and the number and percentage of patients on which they were used are as follows: 14 patients by ball tip probe and radiograph (50.0\%); 6 patients by ball tip probe alone (21.4\%); 3 patients by radiograph alone (10.7\%); 2 patients by straight rod and radiograph $(7.1 \%) ; 1$ patient by a combination of neuro-navigation and ball tip probe $(3.6 \%) ; 1$ patient by straight rod and ball tip probe (3.6\%); and 1 patient by a combination of ball tip probe, straight rod, and radiograph (3.6\%). Thus, a wide variety of instruments were used during the study to check whether perforations had occurred.
The protocol required a postoperative CT scan only if the hospital had a CT scanner. Five patients (17.8\%) had a CT postoperatively that confirmed the intraoperative findings. When using this more definitive method of assessment, PediGuard identified all 5 of the CT scan confirmed pedicle screw breaches.

\section{CONCLUSION}

In this prospective, randomized trial of a pedicle drilling device that uses electrical conductivity differentiation at the tip for assessing bone versus soft tissue, the number of fluoroscopy shots was reduced by $30 \%$ as compared to a standard drilling probe. A $97.5 \%$ safe screw placement was maintained on CT imaging, and no neurological complications or new radicular symptoms occurred.

All the authors declare that there is no potential conflict of interest referring to this article.

\section{REFERENCE}

1. Hackenberg L, Link T, Liljenqvist U. Axial and tangential fixation strength of pedicle screws versus hooks in the thoracic spine in relation to bone mineral density. Spine (Phila Pa 1976). 2002;27(9):937-42

2. Suk SI, Lee CK, Kim WJ, Chung YJ, Park YB. Segmental pedicle screw fixation in the treatment of thoracic idiopathic scoliosis. Spine (Phila Pa 1976). 1995;20(12):1399-405.

3. Liljenqvist U, Lepsien U, Hackenberg L, Niemeyer T, Halm H. Comparative analysis of pedicle screw and hook instrumentation in posterior correction and fusion of idiopathic thoracic scoliosis. Eur Spine J. 2002;11(4):336-43.

4. Suk SI, Lee CK, Min HJ, Cho KH, Oh JH. Comparison of Cotrel-Dubousset pedicle screws and hooks in the treatment of idiopathic scoliosis. Int Orthop. 1994;18(6):341-6.

5. Burton DC, Asher MA, Lai SM. Scoliosis correction maintenance in skeletally immature patients with idiopathic scoliosis. Is anterior fusion really necessary? Spine (Phila Pa 1976). 2000;25(1):61-8.

6. Kuklo TR, Lenke LG, O'Brien MF, Lehman RA Jr, Polly DW Jr, Schroeder TM. Accuracy and efficacy of thoracic pedicle screws in curves more than 90 degrees. Spine (Phila Pa 1976). 2005;30(2):222-6.

7. Kim YJ, Lenke LG, Bridwell KH. Comparative analysis of pedicle screw versus hook instrumentation in posterior spinal fusion of adolescent idiopathic scoliosis: a matched cohort analysis. In: Scoliosis Research Society Annual Meeting, Quebec City, Canada, 2003.

8. Yahiro MA. Comprehensive literature review. Pedicle screw fixation devices. Spine (Phila Pa 1976). 1994:19(Suppl 20):2274-2278.

9. Belmont PJ Jr, Klemme WR, Dhawan A, Polly DW Jr. In vivo accuracy of thoracic pedicle screws. Spine (Phila Pa 1976). 2001;26(21):2340-6.

10. Belmont PJ Jr, Klemme WR, Robinson M, Polly DW Jr. Accuracy of thoracic pedicle screws in patients with and without coronal plane spinal deformities. Spine (Phila Pa 1976). 2002;27(14):1558-66

11. Liljenqvist UR, Halm HF, LinkTM. Pedicle screw instrumentation of the thoracic spine in idiopathic scoliosis. Spine (Phila Pa 1976). 1997;22(19):2239-45.

12. Suk SI, Kim WJ, Lee SM, Kim JH, Chung ER. Thoracic pedicle screw fixation in spinal deformities: are they really safe? Spine (Phila Pa 1976). 2001;26(18):2049-57.

13. Papin $P$, Arlet $V$, Marchesi $D$, Rosenblatt $B$, Aebi M. Unusual presentation of spinal cord compression related to misplaced pedicle screws in thoracic scoliosis. Eur Spine J. 1999:8(2):156-9.

14. Yalçin S, Güven O. Reversible anterior cord syndrome due to penetration of the spinal canal by pedicular screws. Paraplegia. 1995;33(7):423-5.

15. Donovan DJ, Polly DW Jr, Ondra SL. The removal of a transdural pedicle screw placed for thoracolumbar spine fracture. Spine (Phila Pa 1976). 1996;21(21):2495-8.

16. Jendrisak MD. Spontaneous abdominal aortic rupture from erosion by a lumbar spine fixation device: a case report. Surgery. 1986;99(5):631-3.

17. Yuan HA, Garfin SR, Dickman CA, Mardjetko SM. A Historical Cohort Study of Pedicle Screw Fixation in Thoracic, Lumbar, and Sacral Spinal Fusions. Spine (Phila Pa 1976). 1994;19(Suppl 20):2279-96
18. Laine T, Lund T, Ylikoski M, Lohikoski J, Schlenzka D. Accuracy of pedicle screw insertion with and without computer assistance: a randomised controlled clinical study in 100 consecutive patients. Eur Spine J. 2000;9(3):235-40.

19. Perisinakis K, Theocharopoulos N, Damilakis J, Katonis P, Papadokostakis G, et al. Estimation of patient dose and associated radiogenic risks from fluoroscopically guided pedicle screw insertion. Spine (Phila Pa 1976) 2004:29(14):1555-60.

20. UI Haque M, Shufflebarger HL, O'Brien M, Macagno A. Radiation exposure during pedicle screw placement in adolescent idiopathic scoliosis: is fluoroscopy safe? Spine (Phila Pa 1976). 2006:31(21):2516-20.

21. Bolger C, Carozzo C, Roger T, McEvoy L, Nagaria J, Vanacker G, et al. A preliminary study of reliability of impedance measurement to detect iatrogenic initial pedicle perforation (in the porcine model). Eur Spine J. 2006;15(3):316-20.

22. Schulze CJ, Munzinger E, Weber U. Clinical relevance of accuracy of pedicle screw placement. A computed tomographic-supported analysis. Spine (Phila Pa 1976). 1998:23(20):2215-20

23. Laine T, Mäkitalo K, Schlenzka D, Tallroth K, Poussa M, Alho A. Accuracy of pedicle screw insertion: a prospective CT study in 30 low back patients. Eur Spine J. 1997;6(6):402-5.

24. Gertzbein SD, Robbins SE. Accuracy of pedicular screw placement in vivo. Spine (Phila Pa 1976). 1990;15(1):11-4

25. Learch TJ, Massie JB, Pathria MN, Ahlgren BA, Garfin SR. Assessment of pedicle screw placement utilizing conventional radiography and computed tomography: a proposed systematic approach to improve accuracy of interpretation. Spine (Phila Pa 1976). 2004;29(7):767-73

26. Weinstein JN, Spratt KF, Spengler D, Brick C , Reid S. Spinal pedicle fixation: reliability and validity of roentgenogram-based assessment and surgical factors on successful screw placement. Spine (Phila Pa 1976). 1988;13(9):1012-8

27. Klemme WR, Belmont Jr PJ, Polly Jr DW. Transpedicular thoracic screws: genera concepts and insertion technique using fluoroscopic guidance. Sem Spine Surg. 2002;14(1):43-7.

28. Rampersaud YR, Foley KT, Shen AC, Williams S, Solomito M. Radiation exposure to the spine surgeon during fluoroscopically assisted pedicle screw insertion. Spine (Phila Pa 1976). 2000;25(20):2637-45

29. RampersaudYR. Advanced image guidance for the placement of thoracic pedicle screws Sem Spine Surg. 2002:14:58-65

30. Ferrick MR, Kowalski JM, Simmons ED Jr. Reliability of roentgenogram evaluation of pedicle screw position. Spine (Phila Pa 1976). 1997;22(11):1249-52.

31. Clements DH, Morledge DE, Martin WH, Betz RR. Evoked and spontaneous electromyography to evaluate lumbosacral pedicle screw placement. Spine (Phila Pa 1976). 1996;21(5):600-4.

32. Bolger C, Brayda-Bruno M, Kaelin A, Lazennec JY, Le Huec JC, Logroscino C, et al. A new device to detect iatrogenic initial vertebral cortex perforation: first clinical results [abstract]. Eur Spine J. 2003;12(Suppl 1):1-79 